\title{
Syntactical Phenomena Observed in Bringing Swift's Style into Albanian: Case Study "A Tale of a Tub" and Its Variant in Albanian
}

\author{
Msc. Alma Karasaliu \\ Department of Foreign Languages \\ Fan S. Noli University, Korçë \\ almakarasaliu3@gmail.com
}

\section{Doi:10.5901/mjss.2013.v4n10p114}

\begin{abstract}
This study focuses on the syntax and rhythm employed by the author in his satire "A Tale of a Tub", with the view of making an analysis of the effect they have on the message perceived by the reader. Furthermore, by means of analyzing techniques, it will be pointed out that the word order, in Swift's style, represents the process of thinking much more than the finished thought. In this context, it will be highlighted that the syntax employed by the author is often inconsistent with what is normally expressed, revealing, likewise, what Swift, himself, intends to transmit. Making use of contrasting technique, the analysis will be conducted on the way such important elements, part of his style are conveyed to the target language readership, in Albanian. Moreover, it will be pointed out that, in order to preserve contextual synonymy and not to accomplish a literal translation, the translator, Shpëtim Mema has manipulated the sentence structure and punctuation. Also, aiming at creating a parallel background for the target language readership, under the scope of achieving the effect of a 'thinking process' through rhythm, instead of a static thought, and taking into account the fact that Albanian is an inflected language, the translator has manipulated the word order and has partly employed additional prefixes and suffixes.
\end{abstract}

Keywords: syntax, rhythm, word order, punctuation

\section{Introduction}

Our capacity for language enables us to communicate virtually any thought or idea, and this is in largely because of the language faculty evolved in a syntactic component. Syntax allows words to be combined in order to create unique combinations of meaning. And although all human languages share some universal syntactic properties, the constraints on how constituents may be generated vary substantially. English, which is often characterized as a language that offers little in the way of word ordering options (MacWhinney, Bates, \& Reinhold, 1984), allows the speaker to choose from among at least a few different forms to express the same essential idea. What is more, sentence structure and syntax influence style through the lengths of thought units and the patterns of grammatical order. (e.g. whether subjects lead to verbs, objects lead to subjects, etc) Shorter sentences, like shorter words, are generally easier to read. Longer sentences tend to occur in more academic literature or that intended for readers with high levels of formal education. It is worth mentioning that while analyzing the sentence structure, it is necessary to identify sentence patterns, in order to point out the reason the author uses certain syntactic patterns in a given passage.

The principle of rhythmic alternation, on the other hand, has a significant influence on syntactic word order. In a study on word order, in English noun phrase coordination, it is found that words are more likely to be ordered in a way that enhances rhythmic alternation between stressed and unstressed syllables. (Mc Donald, Bock and Kelly 1993) This definition of rhythmicity forms one of the fundamental assumptions of metrical theory: because we expect regularity, languages strive towards a perfect state of rhythmicity, where stress is equally distributed and spaced. (Selkirk 1984; Hayes 1995) One of the most desired rhythmic states in language, then, is a "fundamental contrast between stressed and unstressed syllables" (Schlüter 2005), where exactly one unstressed, weak syllable occurs between each stressed syllable. In this way, it can be stated that language tries to avoid deviation from the equal distribution of stress.

While the interaction of rhythm and syntax has long been noted in the generative literature, the early work in this vein focused largely on the influence of syntax on metrical and prosodic structure. (Vogel and Kenesei, 1990) Recent research, however, has suggested and demonstrated the influence that rhythm, rhythmicity, and the Principle of Rhythmic Alternation can have on syntax. (Selkirk 1984; Hayes 1995) From psycholinguistic studies of processing and production to studies in historical change, rhythm's effects on syntax, and in particular, on the syntactic word order 
choice, are evident. Psycholinguistic experiments have shown that the Principle of Rhythmic Alternation has a significant influence on syntactic word order. In this context, it is truly impossible to judge the actual effect of rhythm on syntax, if it is examined in isolation without controlling for the effects of other non rhythmic conditioning factors, like the presence of an animacy contrast. (Selkirk 1984; Hayes 1995) According to McDonald's results, discounting syntactic, semantic, informational, and sociolinguistic factors in a study of syntactic construction choice is dangerous, as is discounting phonological and rhythmic factors. (Mc Donald, Bock and Kelly 1993)

\section{Special features of Swift syntax and rhythm in "A Tale of a Tub"}

It is widely agreed that the best way to understand a writer's thoughts is paying attention to the syntax in his works. Being very sensitive to the effect of the tone of the voice in writing, the style of Jonathan Swift "is the embodiment of a particular way of thinking, which is being set before us for our contemplation". (Kathleen Williams, 1958) In his writings, the order of the words is to be paid special attention, as in his case, the actual process of thinking is often much more important than the thought itself. Despite representing a completed thought, syntax in Swift's writings always gives the idea of an openended statement. One of the features of the Augustan syntax is the fact that it is based on the stately counter-change of antithesis (Allan Rodway, 1966) and in "A Tale of a Tub", it is often possible to make out a bold antithesis. Anyway, such symmetry is simultaneously obscured by cumulative organization, unfinished antitheses, and unrelenting qualification. It is worth mentioning the fact that, Jonathan Swift's sentences are characterized by incomplete antitheses and many of them represent little dramas between right and wrong ways of thinking. (Smith, Frederik N. 1979)

The rhythm, which represents the movement of the thought through the mind, carries a large amount of importance. Swift seems especially attentive to the subtle effects the sound posses. In the "A Tale of a Tub," he frequently manipulates syntax, along with stress pattern, alliteration, and even meaning, with a view of creating an oratorical cadence and then breaking it later, in order to suggest a more realistic position.

In the following example, Swift mixes the formal rhythms of the Latin with the abrupt rhythms of English monosyllables in order to expose the pretentiousness of Peter as well as that of the Modern. "In which Guise, whoever went to take him by the Hand in the way of Salutation, on the Mouth, Peter with much Grace, like a well educated Spaniel, would present them with his Foot, and if they refused his Civility, then he would raise it as high as their Chops, and give them a damn'd Kick on the Mouth, which hath ever since been call'd a Salute." (Gulliver's Travels, p. 115) The ironic juxtaposition of vocabularies, (Salutation with "Kick on the Mouth"), is strengthened by the similarly ironic juxtaposition of prose rhythms. Swift devotes his rhetorical energies to creating two styles, credible down to their quite different pacings and stress patterns. In documenting the Peter's and the Modern's extreme civility, he employs a higher percentage of polysyllables, uses less emphatic endings, and depends upon a fairly slow, rounded sort of clausal and phrasal rhythm. On the other hand, in pointing up the superficiality of the Peter's and the Modern's civility, he favors monosyllables, uses more emphatic endings, and lets the more frequent stresses break the longer rhythmic patterns. Shifting from one rhythm to another effectively goes beyond our expectations and sets up an ironic tension, which allows us to get the impact of the monosyllables he uses in the passage.

\subsection{Two different types of syntax}

The relationship between one type of syntax or rhythm and another is an important aspect of Swift's irony. There are instances, in his work, where the formality or informality implied in the syntax clashes with the subject, diction, or tone. (Smith, Frederik N. 1979) In some other cases, there is a sudden drop from a periodic, Ciceronian syntax to a loose, Senecan one. Ciceronian syntax depicts a finished thought, a balanced and periodic prose, while the later, a mind thinking, which is looser, more cumulative and assymetrical. (Morris W. Croll, 1966) In this context, it is worth mentioning the fact that the writer exploits both of the syntaxes, combining, thus the symmetrical syntax with the asymmetrical one. He uses Ciceronian syntax in Modern's speech to represent his attempt at arranging his material in neat packages of ancient and modern, right and wrong, reasonable and unreasonable.

But, on the other hand, Swift makes his persona slip continuously from balance and periodicity into a loose, absurdly cumulative rhythm that we ought to understand as his way of registering doubt concerning the Modern's proud categorizations. In addition, in some instances, a certain prose rhythm is played off against a certain type of syntax. In such a case, the rhythm suggests one attitude toward the subject and the syntax another one. Shifting from a formal, rounded rhythm to a more heavily stressed rhythm is also found in this satire. It is worth mentioning the fact that by making use of all these devices, the writer aims at creating the effect of incongruity. 
"A Tale of a Tub" reveals a parallel structure of the Modern's rhetoric, which represents all the techniques of balance, antithesis, and logic, and Swift's own loose, asymmetrical style of actual speech. Swift's juxtaposition of one type of syntax to another implies a clash of two approaches to the world: the real and the artificial one. (Smith, Frederik N. 1979)

\subsection{Syntactical incongruities}

There are cases when a sentence in "A Tale of a Tub" often begins with a logical comparison but soon becomes cumulative, getting tangled in its own examples and in the end it is difficult to get the right idea of what is the writer's real attitude towards what is expressed. One of such cases is the sentence: "The Conclusion of a Treatise, resembles the Conclusion of Human Life, which hath sometimes been compared to the End of a Feast; where few are satisfied to depart, ut plenus vitae conviva: For Men will sit down after the fullest Meal, tho' it be only to doze, or to sleep out the rest of the Day" ("A Tale of a Tub", p. 208). If we closely observe the sentence, we notice the analogy the writer uses while comparing a 'treatise' with 'human life' and 'the end of a feast' and moreover, he uses a Latin clause which makes it even harder for the reader to get the meaning of what is intended by the author. This incongruity is evident in a lot of other examples, where the writer, aiming at shaping the character of the 'wise' Modern employs several Latin words and phrase, like: 'Arcanum' (p.127), 'in via humida' (p. 121), 'opus magnum' (p. 127, 187), etc.

Another such case is the following one: "I conceive therefore, as to the Business of being profound, that it is with writers as with Wells; A Person with good Eyes may see to the Bottom of the deepest, provided ant Water be there; and, that, often, when there is nothing in the World at the Bottom, besides Dry ness and Dirt, tho' it be but a Yard and half under Ground, it shall pass, however, for wondrous Deep, upon no wiser Reason than because it is wondrous Dark. ("A Tale of a Tub", p. 207) If carefully observed, the logical conjuctions 'therefore', 'however' and 'because' do not relate very much to the cumulative nature of the argument. In this sentence, we note the writer's attitude towards what he is saying, which asserts that a thing means something, or something, or something else and this multiplicity of interpretation suggests that the author has meant to say whatever we think he has.

"Thus furnisht, and set out with Gods, as well as Devils, was the renowned Sect of Aeolists; which makes at this Day so illustrious a Figure in the World, and whereof, that Polite Nation of Laplanders, are beyond all doubt, a most Authentic Branch; Of whom, I therefore cannot, without Injustice, here omit to make honourable Mention; since they appear to be so closely allied in Point of Interest, as well as Inclinations, with their Brother Aeolists among Us, as not only to buy their Winds by wholesale from the same Merchants, but also to retail them after the same Rate and Method, and to Customers much alike." ("A Tale of a Tub", p.160) The opening clause in this extremely loose sentence, sounds deceptively complete in itself and the term "Thus" makes it appear like a summary. Also, there are numerous pairs of terms here, and although most of the sentence is based, on a comparison, it is in this case difficult to tell what is exactly being compared.

Taking into consideration the word order, it is important to highlight that as previously seen, in the provided examples, the words and clauses in this book are grouped in series of three, four, five or more and no matter how many items in a series, that series remains incomplete and open to at least one more item, for ex: "... these Events, I say, and some Others too long to recite." ("A Tale of a Tub", p. 183)

\subsection{Punctuation characteristics in the satire}

One of Swift's most prominent abilities is his ability to laugh at himself. Although the Modern repeatedly distinguishes between an idea "wholly neglected or despised in discourse" and "its preferment and sanction in print", Swift refutes this claim in every page of the book. Swift denies the likelihood of fixing ideas into any kind of black-and-white assertiveness. (Smith, Frederik N. 1979) There are cases, in the book, where the author has partly taken out entire clauses so as to

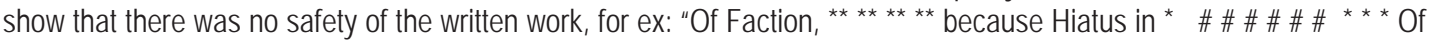
Poetry, because its ..." ("A Tale of a Tub", p. 62-63) The presence of the blank spaces is partly used to demonstrate that ideas committed to paper are guaranteed no certainty and partly to show "that white paper void all characters". (Kathleen Williams, 1958)

Another phenomenon is the incongruity among the footnotes and what they point up. In most of the cases, they explain what is mentioned in the article like in the case: "This is an imaginary Island, of Kin to ..." ("A Tale of a Tub", p. 125), while in another case the author, in stead of giving an explanation of what is mentioned in the text, takes himself completely out of his role and shows himself unable to explain it as in: "I cannot conjecture what the Author means here, 
or how this Chasm could be fill'd, tho it is capable of more than one interpretation." ("A Tale of a Tub", p. 179) Also, in another case, the author makes fun of what is said in the text, pointing out that the author of the text is mistaken on what he is declaring, for ex: "The Author seems to be mistaken, for I have seen a Latin Edition of Reynard the Fox, above an Hundred years old, which I take to be the Original; for the rest it has been thought by many People to contain some Satyrical Design in it." ("A Tale of a Tub", p. 68) The way the author has named the chapters is another worth mentioning issue. In this way, we see that he includes an "Apology", a "Dedication", "Bookseller to the Reader", "The preface", "Introduction", "To his Royal Highness Prince Posterity", etc, which in deed makes it tiresome for the reader to concentrate and to remember what he has been reading about.

\section{Examples of translation phenomena of the book "A Tale of a Tub"}

The translation of a book requires not only the conveyance of what is said by the author of the book but also what is meant to, in order to save the tone the author uses and the hidden messages he intends to imply. In addition, a good knowledge of the book's cultural and historical background is needed, in order to understand the book preserving, likewise, contextual synonymy without which the translated version will not be adequately understood.

With the view of transmitting the exact meaning intended by the author the translator gives the phrase "Powder Pimperlim pimp" ("A Tale of a Tub", p.320) as "pluhurit të tij të famshëm pimperlim pimp" ("Përralla e fuçisë", p. 303-4), adding likewise the pronoun 'të tij' and the adjective 'të famshëm', in order to make clear the presence of the powder.

The phrase "... Spargefaction in a proper Time of the Moon." ("A Tale of a Tub", p.320) has been given as "... me spërkatje në një periudhë të përshtatëshme të vitit, p.sh. kur hëna ishte pesëmbëdhjetë". ("Përralla e fuçisë", p. 304) In this case, in order to achieve contextual and cultural equivalence, the translator extends the sentence, providing additional information and translates it with another equivalent one, preserving, likewise, the intended message and adopting it with the rules of Albanian language and figurative usage.

Aiming at transmitting situational equivalence to the reader of the target language, the translator has conveyed the nouns of the sentence: "His epidemical Diseases being Fastidiosity, Amorphy, and Oscitation; whereas in the present universal Empire of Wit and learning, there seems but little Matter left for Instruction". ("A Tale of a Tub", p.124) as "Dhe më tej, kam provuar nga leximet e shumta të përmendura më sipër, se për konditat në të cilat ndodhet sot njerëzimi, mund të thuhet me bindje se ai përfiton shumë më tepër nga dëfrimet dhe zbavitjet sesa nga të mësuarit dhe studimi, për shkak se ai vuan më shumë nga sëmundja epidemike e amullisë, neverisë për gjith/ka dhe letargjisë, ndërkohë që, me sa duket, në perandorinë e tanishme universale të mendimit dhe të diturisë pak gjë ka mbetur për tu mësuar." ("Përralla e fuçisë", p. 316) As it can easily be noticed, the sentence in Albanian variant is extended and is provided with further information. Word order is another element worth to be mentioned. The translator, in accordance with the impact the translated variants for the nouns 'Fastidiosity', 'Amorphy', and 'Oscitation' have in Albanian language, changes their order and gives it as 'amullisë', 'neverisë për gjith/ka' and 'letargjisë', in order to create a parallel impact with the one created by the text in the source language. Another prominent example of the translators usage of cultural equivalent referents is the case "...never to change his Title or his Nature; that a Grey critick has been certainly a Green one, the Perfections and ..." ("A Tale of a Tub", p.101) where the noun phrase 'grey critick' has been translated as 'kritik i pjekur e i zbardhur nga flokët' while that 'a Green one' as 'aguridh dhe jeshil' in "... ai kurrë s'e ndërron titullin dhe natyrën e vet; dhe dihet se një kritik i pjekur e i zbardhur nga flokët, dikur, me siguri ka qënë aguridh dhe jeshil dhe se përvoja dhe arritjet e moshës ..." ("Përralla e fuçisë", p. 296).

The translator uses word-for-word translation to give the phrase 'like Hemp' in the sentence "... like Hemp, which some naturalists inform us, is bad for ..." ("A Tale of a Tub", 101) into that 'si puna e kërpit' in the sentence "... si puna e kërpit për të cilin disa natyralistë na informojnë se është i keq, ..." ("Përralla e fuçisë", p. 298).

There are other cases where the translator has seen it useful to leave out of the translated version entire sentences like: "The first of these ... to Customers much alike." ("A Tale of a Tub", 159) or "It is true ...ancestors and Sibyls." ("A Tale of a Tub", 159). This action, in fact has led to a lack of understanding the passages and to a confusion due to his attempt at reshaping the idea in the other paragraphs.

\section{Conclusions}

Despite the haphazard appearance of this book, the author has carefully calculated its effects. The formlessness of the book is meant to reflect the trouble the Modern encounters in his attempts to make literary sense out of the actual events and personal opinions. Thus, "A Tale of a Tub" is not fiction in the ordinary sense, but a book about the nonsense of 
assuming that reality can be frost into fictional form. In addition, Jonathan Swift emphasizes his syntactic parallelism by means of rhythm, alliteration and capital letters.

In Swift's satire, the complexity of the relationship between form and meaning is connected to his characteristic complexity of the point of view. It is often in contradiction with what is expressed in the sentence and in accordance with what the author intends to imply.

The translator of the book, Halit Selfo, has provided the reader of the target language with a $\mathrm{n}$ equivalent and culturally understandable translation. In most of the cases, he has managed to imply the same messages the author of the original intended to, but in some other cases, he has not included entire passages in the translated version which normally causes a feeling of confusion and of emptiness among the reader of the target language.

\section{References}

Croll, Morris W. (1966). Style, Rhetoric, and Rhythm, Ed. J. Max Patrick and Robert O. Evans, Princeton University Press, Princeton, New Jersey

Hayes, B. (1995). Metrical stress theory. Chicago: University of Chicago Press.

MacWhinney, B., Bates, E., \& Reinhold, K. (1984). Cue validity and sentence interpretation in English, German, and Italian. Journal of Verbal Learning and Verbal Behavior, 23, 127-150.

McDonald, J. L., Bock, K. \& Kelly, M. H. (1993). Word and world order: Semantic, Phonological and metrical determinants of serial order. Cognitive Psychology, 25, 188-230.

Rodway, A. (1966). "By Algebra to Augustanism," in Essays on Style and Language: Lingusitic and Critical Approaches to Literary Style, ed. Roger Fowler (London)

Schlüter, J. (2005). Rhythmic Grammar: The Influence of Rhythm on Grammatical Variationand Change in English.Berlin: Mouton de Gruyter

Selkirk, E. (1984). Phonology and syntax: The relation between sound and structure. Cambridge: MIT Press.

Smith, Frederik N. (1979). Language and Reality in Swift's "A Tale of a Tub", Ohio State University Press: Columbus

Vogel, I. and Kenesei, I. (1990). Syntax and Semantics in Phonology. In: S. Inkelas and D. Zec (eds.) The phonology-syntax connection, 339-363. Chicago: University of Chicago Press.

Williams, K. (1958). Jonathan Swift and the Age of Compromise (Lawrence, Kans.) 